Article

\title{
Applying Risk Indices to Assess and Manage Soil Salinization and Sodification in Crop Fields within a Mediterranean Hydro-Agricultural Area
}

\author{
Alexandra Tomaz ${ }^{1,2, * \mathbb{D}}$, Maria João Costa ${ }^{3,4,5} \mathbb{D}$, João Coutinho ${ }^{6} \mathbb{D}$, José Dôres ${ }^{1}$, Adriana Catarino ${ }^{1} \mathbb{D}$, \\ Inês Martins ${ }^{1}$, Clarisse Mourinha ${ }^{1}$, Isabel Guerreiro ${ }^{1}$, Maria Margarida Pereira ${ }^{1}$, Marta Fabião ${ }^{7}$, Luís Boteta ${ }^{7}$, \\ Manuel Patanita ${ }^{1,2}$ and Patrícia Palma ${ }^{1,4}$ (D)
}

\section{check for}

updates

Citation: Tomaz, A.; Costa, M.J.; Coutinho, J.; Dôres, J.; Catarino, A.; Martins, I.; Mourinha, C.; Guerreiro, I.; Pereira, M.M.; Fabião, M.; et al. Applying Risk Indices to Assess and Manage Soil Salinization and Sodification in Crop Fields within a Mediterranean Hydro-Agricultural Area. Water 2021, 13, 3070. https:// doi.org/10.3390/w13213070

Academic Editor: Renato Morbidelli

Received: 29 September 2021

Accepted: 28 October 2021

Published: 2 November 2021

Publisher's Note: MDPI stays neutral with regard to jurisdictional claims in published maps and institutional affiliations.

Copyright: (c) 2021 by the authors Licensee MDPI, Basel, Switzerland. This article is an open access article distributed under the terms and conditions of the Creative Commons Attribution (CC BY) license (https:// creativecommons.org/licenses/by/ $4.0 /)$.
1 Escola Superior Agrária, Instituto Politécnico de Beja, R. Pedro Soares S/N, 7800-295 Beja, Portugal; jdores@ipbeja.pt (J.D.); adri.catarino@hotmail.com (A.C.); nocaas93@hotmail.com (I.M.); clarisse.mourinha@ipbeja.pt (C.M.); iguerreiro@ipbeja.pt (I.G.); mpereira@ipbeja.pt (M.M.P.); mpatanita@ipbeja.pt (M.P.); ppalma@ipbeja.pt (P.P.)

2 GeoBioTec, NOVA School of Science and Technology, Campus da Caparica, 2829-516 Caparica, Portugal

3 Earth Remote Sensing Laboratory (EaRSLab), Universidade de Évora, 7000-671 Évora, Portugal; mjcosta@uevora.pt

4 Instituto de Ciências da Terra (ICT), Universidade de Évora, 7000-671 Évora, Portugal

5 Departamento de Física, Escola de Ciências e Tecnologia, Universidade de Évora, 7000-671 Évora, Portugal

6 Centro de Química, Universidade de Trás-os-Montes e Alto Douro, Quinta de Prados, 5000-801 Vila Real, Portugal; j_coutin@utad.pt

7 Centro Operativo e de Tecnologia de Regadio, Quinta da Saúde, Apartado 354, 7800-999 Beja, Portugal; marta.fabiao@cotr.pt (M.F.); luis.boteta@cotr.pt (L.B.)

* Correspondence: atomaz@ipbeja.pt; Tel.: +351-284214300

Abstract: Irrigation-induced or secondary salinization can occur when salts are introduced by irrigation water and accumulate within the root zone due to insufficient leaching. Mediterranean regions are especially susceptible, given the predominant climate and the expanding of irrigation areas. In this study, two indices to assess the risk of salinization (RSA) and sodification (RSO), previously applied at a regional scale, were used in a hydro-agricultural area (AHA) in Southern Portugal, in ten crop fields. Information on climate, irrigation water quality, soil characteristics, and land use was obtained from large databases and from local data. The results revealed the feasibility of using the RSA and RSO indices both on large and smaller scales, seeing as most of the area in the monitored crop fields presented the same risk classes (62\% in RSA and 78\% in RSO). Deviations were due to the reduction in scores for drainage and, in the case of RSO, the assigned irrigation method based on the land occupation class. Considering that different spatial scales of risk assessment are associated with different objectives and management options, a risk management framework was outlined following a multi-scale perspective for mitigation actions in salt-sensitive areas, ranging from territorial planning to the adoption of on-farm practices that can contribute to the sustainability of irrigated agriculture.

Keywords: irrigation water quality; irrigation areas; risk assessment; soil salinization; soil sodification; soil and water management practices

\section{Introduction}

Soil quality declines when affected by salinization processes which reduce the soil capacity to provide ecosystem services, such as physical support for plants, nutrient cycling, and the regulation of the water supply or habitat for microorganisms [1,2]. Soil salinization problems are related with excessive concentrations of either soluble salts or exchangeable sodium ( $\mathrm{Na}$ ) [3]. An excess of soluble salts in the soil, or soil salinity, results in increased osmotic stress, affecting water uptake and causing ion toxicities or an imbalanced 
accumulation of specific ions in plants; the dominance of $\mathrm{Na}$ in the soil exchange complex, or soil sodicity, may lead to the dispersion of soil colloids that affects the movement of water and air, with soils becoming prone to the formation of surface crusts, thereby hindering the emergence of seedlings, causing water stagnation, reducing infiltration, and creating anoxic conditions [4].

Salt-affected soils are widely distributed in the world, typically in areas where potential evapotranspiration is higher than precipitation or in areas with high water tables [5]. Irrigation-induced or secondary salinization can occur when salts are introduced by irrigation water and accumulate within the root zone due to insufficient leaching, a process that is intensified by factors such as poor-quality irrigation water, low hydraulic conductivity of soil layers, or high evaporative conditions [6]. It is estimated that more than $20 \%$ of the world's irrigated area is affected by salinization caused by irrigation [7]. In Mediterranean regions, $25 \%$ of irrigated cropland is affected by moderate to high salinization processes [8]. An increased temperature and changes in regional precipitation patterns resulting from climate change, along with water quality degradation, could contribute to the increase in salt-affect areas [9-13]. Additionally, the expansion of irrigation areas is characterized by rapid changes in land use and the redistribution of water resources, therefore reshaping the spatial heterogeneity of soil salinity [14,15].

In irrigated agroecosystems, salt-affected soils vary spatially and temporally, depending, among other factors, on climate, soil physicochemical properties, topography, irrigation water quality, and irrigation systems [6]. Thereby, any risk assessment methodology must be based on robust indicators to assess whether a given soil could be affected by secondary salinization. Risk assessment methods can be performed at different levels of spatial and temporal scales and associated levels of detail, in each case using different types of approaches, namely, a qualitative, quantitative, or model approach [16,17]. Tomaz et al. [18] proposed two indices to assess the risk of soil salinization (RSA) and soil sodification (RSO) at a regional scale, based on easily available data. The RSA index was obtained from a set of four indicators, namely, the aridity index, slope, soil drainage, and irrigation water quality. In the case of RSO, the type of irrigation method was added as a fifth indicator. The aim of the RSA and RSO indices was to provide a straightforward tool to help identify susceptible areas, to select appropriate agronomical strategies and management options, and to prevent soil degradation in irrigated lands. It is useful, from the standpoint of the differentiated and sustainable management of soil and water resources, to understand whether these indices have the potential to be used with greater spatial resolution at the scale of farms and agricultural plots.

Crop type, water quality, and soil properties determine to a large extent the management practices required to optimize production in salt-sensitive areas [19]. In order to achieve a long-term "salt" sustainability of an irrigated field or an irrigation plan, the monitoring and assessment of water quality for irrigation should be complemented with the recommendation of appropriate agricultural water management options for preventing those impacts [10]. Furthermore, control measures of soil salinity/sodicity must be implemented to sustain irrigated agriculture and to prevent the pollution of associated water resources. Such measures must be chosen with recognition of the natural processes operative in irrigated, geohydrologic systems, not just those on-farm, and with an understanding of how they affect the quality of soil and water resources in addition to crop production limitations [20]. The strategies that can be used to prevent, reduce, or adapt to soil salinity or sodicity vary as a function of the level of risk assessed but its implementation must also take into account the spatial scale of assessment. Thereby, the risk management needs to be adapted to different scales, from the cultivation field level to the regional/landscape level, using integrated approaches [21,22].

Taking into account the above considerations, with this study we intended to: (i) compare the salinization and sodification risk assessment based on easily available data at the hydro-agricultural area (AHA) scale, and, based on more detailed data obtained from in situ monitoring, at the crop field scale; (ii) evaluate the feasibility of using the RSA and 
RSO indices at the crop field scale; (iii) outline a multi-scale risk management framework for salt-sensitive areas in irrigated agroecosystems.

\section{Materials and Methods}

\subsection{Study Area}

\subsubsection{Hydro-Agricultural Area}

The AHA of Brinches-Enxoé was considered for the irrigation plan scale assessment. This AHA, located on the left bank of the Guadiana Basin (South Portugal), is one of the 21 areas of the Alqueva irrigation plan, part of the Multipurpose Development of Alqueva (EFMA-Empreendimento de Fins Múltiplos de Alqueva), centered in the Alqueva reservoir and presently covering 120,000 ha. The AHA of Brinches-Enxoé has both pressurized and gravity conveyance networks, with origins in the Laje reservoir and the Montinhos reservoir, respectively. The equipped area is 5061 ha with 3976 ha under exploration in 2018. The climate in the region is mainly temperate with a hot and dry summer (Mediterranean) with an annual precipitation and average mean monthly temperature of, respectively, $558 \mathrm{~mm}$ and $16.9^{\circ} \mathrm{C}$ (long-term means for the 1981-2010 period, [23]). During 2018, data from an automatic meteorological station $\left(37.97^{\circ} \mathrm{N} ; 7.55^{\circ} \mathrm{W}\right)$ of the Irrigation Operating and Technology Center (Centro Operativo e de Tecnologia do Regadio-COTR) located in the AHA, near the monitored crop fields, showed that the annual precipitation was $603 \mathrm{~mm}$, and the mean temperature was $16.7^{\circ} \mathrm{C}$. The year was characterized by a very rainy spring, particularly in the months of March $(200 \mathrm{~mm})$ and April $(70 \mathrm{~mm})$. Predominant soils are Vertisols, Cambissols, and Luvisols (Figure 1).

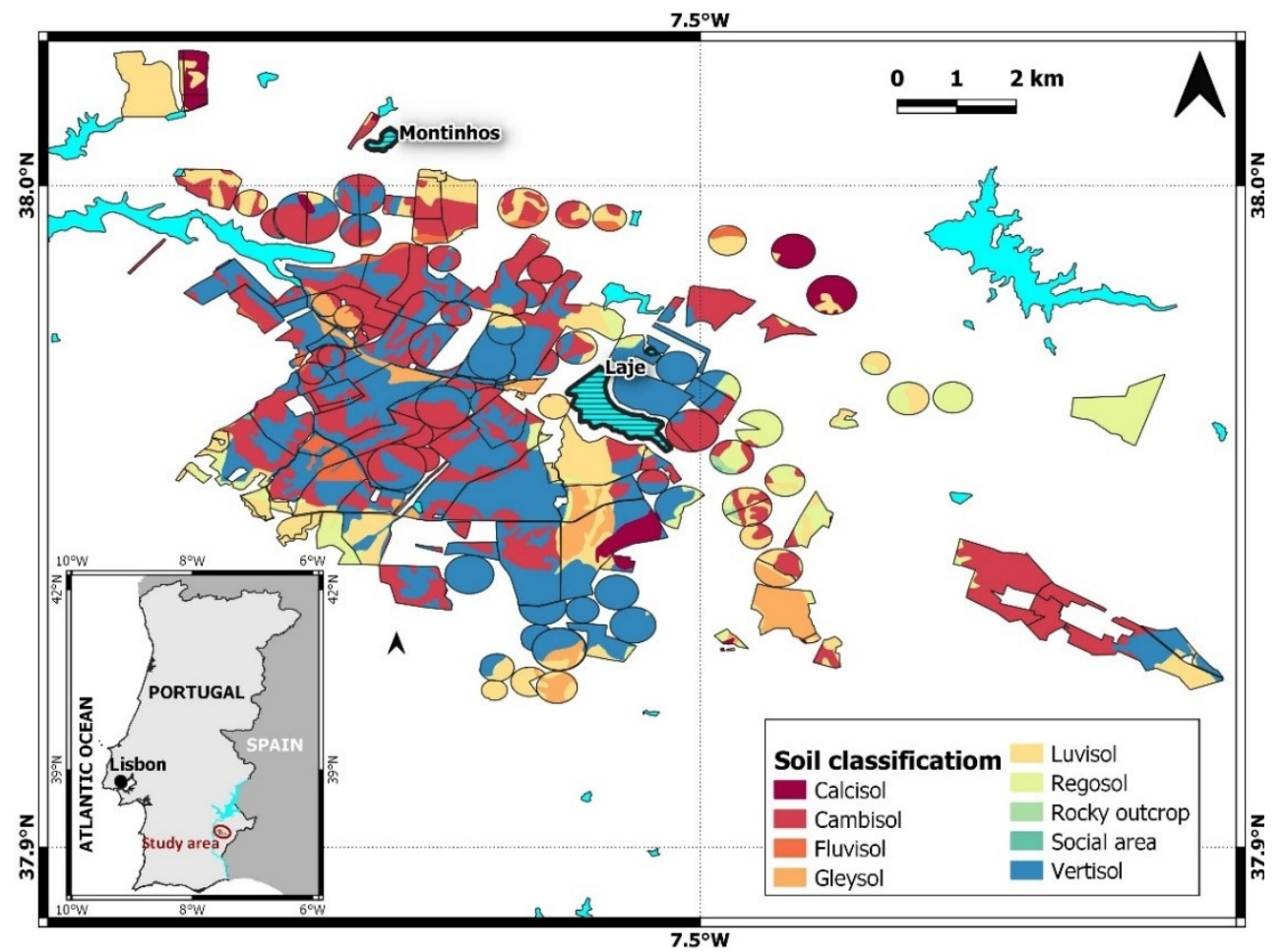

Figure 1. Reference Soil Groups (RSG) of the AHA of Brinches-Enxoé (based on [24-26]) and position of Laje and Montinhos reservoirs in the area (line pattern filled in the map). The bottom-left inset shows the location of the AHA under study.

\subsubsection{Irrigated Crop Fields}

For the crop field level risk assessment, ten agricultural fields, accounting for an area of $125 \mathrm{ha}$, within the Brinches-Enxoé area were evaluated. The ten farm plots were distributed over 88 ha of field, grass, and forage crops; 22 ha of intensive olive groves; and 15 ha of vineyards (Table 1). These fields were assessed under the project Fitofarmgest that 
aimed at the study of the sustainable management of pesticides in olive groves, vineyards, and field crops in the EFMA's area. Soils in the farm plots were conventionally tilled, as commonly performed by the farmers, except for maize, which was planted as a second crop in rotation shortly after the harvest of an Autumn-Winter cereal.

Table 1. General characterization of the crop fields monitored in the study.

\begin{tabular}{|c|c|c|c|c|}
\hline Crop $^{1}$ & Monitored Area (ha) & Predominant Soil Types $^{2}$ & Irrigation Method & Irrigation Hydrant \\
\hline Alfalfa (Medicago sativa L.) (A) & 27.6 & $\begin{array}{l}\text { Calcaric Cambisols; } \\
\text { Regosols }\end{array}$ & Sprinkler & H33 \\
\hline $\begin{array}{c}\text { Permanent Pasture (grasses } \\
(70 \%) \text {, legumes }(18 \%) \text { and } \\
\text { others }(12 \%))(\mathrm{P})\end{array}$ & 21.7 & $\begin{array}{l}\text { Calcaric Cambisols; } \\
\text { Chromic Luvisols; } \\
\text { Regosols }\end{array}$ & Sprinkler & $\mathrm{H} 22$ \\
\hline $\begin{array}{l}\text { Grapevine (Vitis vinifera L. Cv. } \\
\text { 'Antão Vaz) (G1) }\end{array}$ & 4.5 & Chromic Vertisols & Drip & $\mathrm{H} 23$ \\
\hline $\begin{array}{c}\text { Sunflower (Helianthus annus } \\
\text { L.) (S1) }\end{array}$ & 13.1 & $\begin{array}{l}\text { Calcaric Cambisols; } \\
\text { Chromic Vertisols }\end{array}$ & Sprinkler & $\mathrm{H} 23$ \\
\hline $\begin{array}{l}\text { Olive (Olea europaea L. Cv. } \\
\text { 'Cobrançosa') (O1) }\end{array}$ & 8.0 & $\begin{array}{c}\text { Chromic Vertisols; Pellic } \\
\text { Vertisols }\end{array}$ & Drip & $\mathrm{H} 21$ \\
\hline $\begin{array}{c}\text { Sunflower (Helianthus annus } \\
\text { L.) (S2) }\end{array}$ & 15.0 & $\begin{array}{c}\text { Pellic Vertisols; Calcaric } \\
\text { Vertisols }\end{array}$ & Sprinkler & $\mathrm{H7}$ \\
\hline $\begin{array}{l}\text { Grapevine (Vitis vinifera L. Cv. } \\
\text { 'Aragonez) (G2) }\end{array}$ & 9.0 & $\begin{array}{l}\text { Calcaric Cambisols; } \\
\text { Chromic Vertisols }\end{array}$ & Drip & H5 \\
\hline Maize (Zea mays L.) (M) & 10.3 & $\begin{array}{l}\text { Calcaric Cambisols; } \\
\text { Chromic Vertisols }\end{array}$ & Sprinkler & H6 \\
\hline $\begin{array}{l}\text { Grapevine (Vitis vinifera L. Cv. } \\
\text { 'Antão Vaz) (G3) }\end{array}$ & 1.5 & $\begin{array}{l}\text { Chromic Luvisols; } \\
\text { Calcaric Cambisols }\end{array}$ & Drip & H16 \\
\hline $\begin{array}{c}\text { Olive (Olea europaea L. Cv. } \\
\text { 'Cordovil') (O2) }\end{array}$ & 14.0 & $\begin{array}{c}\text { Calcaric Cambisols; } \\
\text { Chromic Vertisols; Vertic } \\
\text { Luvisols }\end{array}$ & Drip & H16 \\
\hline
\end{tabular}

${ }^{1}$ Crop and attributed symbol. ${ }^{2}$ RSG-Reference Soil Group and principal qualifiers, when applicable (according to the World reference base for soil resources classification [24]).

Solid fertilizers used were mainly binary or ternary formulations of Nitrogen, Phosphorus, and Potassium $\left(\mathrm{kg} \mathrm{N} \mathrm{ha}^{-1} ; \mathrm{kg} \mathrm{P}_{2} \mathrm{O}_{5} \mathrm{ha}^{-1} ; \mathrm{kg} \mathrm{K}_{2} \mathrm{O} \mathrm{ha}^{-1}\right.$ ) applied at sowing or at the beginning of the vegetative cycle using localized placement and broadcasting (Table 2). Water-soluble and liquid fertilizers, applied over the crops' cycle through irrigation water, were mostly nitrogen fertilizers but also included other fertilizers containing Sulfur $\left(\mathrm{kg} \mathrm{SO}_{2} \mathrm{ha}^{-1}\right)$, Iron $\left(\mathrm{kg} \mathrm{Fe}\right.$ chelates ha $\left.{ }^{-1}\right)$, or Calcium $\left(\mathrm{kg} \mathrm{CaO} \mathrm{ha}^{-1}\right)$. Foliar applications of Boron $\left(\mathrm{kg} \mathrm{B} \mathrm{ha}^{-1}\right)$ were employed in some of the crops.

Table 2. Main crop management data in 2018.

\begin{tabular}{|c|c|c|c|c|c|c|c|c|c|}
\hline Crop & $\begin{array}{c}\text { Sowing/ } \\
\text { Beginning of } \\
\text { Cycle (dd/mm) }\end{array}$ & $\begin{array}{c}\text { Seasonal } \\
\text { Irrigation } \\
\text { Water }\left(\mathrm{m}^{3}\right. \\
\left.\mathrm{ha}^{-1}\right)\end{array}$ & $\begin{array}{c}\text { First } \\
\text { Irrigation } \\
(\mathrm{dd} / \mathrm{mm})\end{array}$ & $\begin{array}{c}\text { Last } \\
\text { Irrigation } \\
(\mathrm{dd} / \mathrm{mm})\end{array}$ & $\begin{array}{c}\text { N (kg N } \\
\left.\text { ha }^{-1}\right)\end{array}$ & $\underset{\left.\mathrm{ha}^{-1}\right)}{\mathrm{P}\left(\mathrm{kg} \mathrm{P}_{2} \mathrm{O}_{5}\right.}$ & $\underset{\left.\mathrm{ha}^{-1}\right)}{\mathrm{K}\left(\mathrm{kg} \mathrm{K}_{2} \mathrm{O}\right.}$ & $\begin{array}{c}\text { Other } \\
\text { Fertilizers } \\
\left(\mathrm{kg} \mathrm{ha}^{-1}\right)\end{array}$ & $\begin{array}{l}\text { Harvest } \\
\text { (dd/mm) }\end{array}$ \\
\hline $\mathrm{A}$ & $26 / 04$ & 4000 & $01 / 05$ & $30 / 09$ & 10 & 10 & - & - & -1 \\
\hline $\mathrm{P}$ & -2 & 1000 & $15 / 05$ & $15 / 10$ & 43 & - & - & $6 \mathrm{CaO}$ & - \\
\hline G1 & $15 / 03$ & 3960 & $28 / 06$ & $30 / 10$ & 50 & 50 & 56 & - & $31 / 08$ \\
\hline S1 & $18 / 04$ & 2517 & $19 / 04$ & $01 / 08$ & 127 & 34 & - & $16 \mathrm{SO}_{2} ; 0.2 \mathrm{~B}$ & $27 / 08$ \\
\hline $\mathrm{O} 1$ & $07 / 02^{3}$ & 3300 & $01 / 04$ & $30 / 09$ & 83 & 84 & 92 & $0.3 \mathrm{~B}$ & $06 / 12$ \\
\hline S2 & $27 / 04$ & 4606 & $28 / 04$ & $26 / 08$ & 109 & $\begin{array}{l}04 \\
40\end{array}$ & 12 & $16 \mathrm{SO}_{2}$ & $18 / 09$ \\
\hline G2 & $02 / 04$ & 2600 & $04 / 06$ & $10 / 09$ & 96 & 102 & 179 & $8 \mathrm{Fe} ; 53 \mathrm{CaO}$ & $24 / 09$ \\
\hline $\mathrm{M}$ & $18 / 07$ & 4800 & $18 / 07$ & $04 / 10$ & 202 & 144 & 216 & $27 \mathrm{SO}_{2}$ & $17 / 01^{4}$ \\
\hline G3 & $15 / 03$ & 3000 & $15 / 05$ & $15 / 10$ & 66 & 21 & 51 & - & $23 / 08$ \\
\hline $\mathrm{O} 2$ & $15 / 01^{3}$ & 1700 & $15 / 05$ & $23 / 10$ & 69 & 24 & 35 & - & $21 / 11$ \\
\hline
\end{tabular}

${ }^{1}$ Pluriannual forage ( 2 to 3 cuts per year). ${ }^{2}$ Permanent pasture ( $>10$ years) with continuous grazing. ${ }^{3}$ Date of the first fertilization

${ }^{4}$ Delayed harvest due to the occurrence of a long rainy period following the physiological maturity stage. 


\subsection{Risk Assessment}

The Salinization Risk (RSA) index and the Sodification Risk (RSO) index, proposed by Tomaz et al. [18], were used. The RSA and RSO indices incorporate sets of 4 and 5 indicators, respectively, and their value is obtained by their score sum, as presented in Equations (1) and (2):

$$
\begin{gathered}
R S A=\sum_{i=1}^{4} S_{i}=S_{A I}+S_{S l}+S_{S D}+S_{E C w} \\
R S O=\sum_{i=1}^{5} S_{i}=S_{A I}+S_{S l}+S_{S D}+S_{I M}+S_{E C w \wedge S A R}
\end{gathered}
$$

where $S_{i}$ is the rating score assigned to each of the indicators' class, as given in Table 3, namely: $S_{A I}$-Aridity Index class score $\left(S_{i}=1,2, \ldots\right.$, or 5$) ; S_{S l}$-Slope (\%) class score $\left(S_{i}=1,3\right.$, or 5$) ; S_{S D}$-Soil drainage class score $\left(S_{i}=1,3\right.$, or 5$) ; S_{E C w}$-Water salinity (electrical conductivity; $\left.\mathrm{dS}^{-1}\right)$ class score $\left(S_{i}=1,3\right.$, or 5); $S_{I M}$-Irrigation method score $\left(S_{i}=1\right.$ or 5$) ; S_{E C W \wedge S A R}$-Water sodicity (electrical conductivity and Sodium adsorption ratio) class score $\left(S_{i}=1,3\right.$, or 5$)$. The sodium adsorption ratio was given by Equation (3):

$$
S A R=\frac{\left[\mathrm{Na}^{+}\right]}{\sqrt{\frac{\left[\mathrm{Ca}^{2+}\right]+\left[\mathrm{Mg}^{2+}\right]}{2}}},
$$

where $\left[\mathrm{Na}^{+}\right],\left[\mathrm{Ca}^{2+}\right]$, and $\left[\mathrm{Mg}^{2+}\right]$ are the concentrations of Sodium, Calcium, and Magnesium

\begin{tabular}{|c|c|c|c|c|c|}
\hline \multirow{2}{*}{ Indicator } & \multicolumn{5}{|c|}{ Rating Score } \\
\hline & 1 & 2 & 3 & 4 & 5 \\
\hline AI-Aridity Index ${ }^{1}$ & $\geq 0.65$ (Humid) & $\begin{array}{c}0.50-0.65 \text { (Dry } \\
\text { sub-humid) }\end{array}$ & $0.20-0.50$ (Semi-arid) & $0.05-0.20$ (Arid) & $<0.05$ (Hyper-arid) \\
\hline Sl-Slope $(\%)$ & $>9$ & - & $3-8$ & - & $0-2$ \\
\hline $\begin{array}{l}\text { SD_Soil Drainage } \\
\text { class }^{2}\end{array}$ & Good & - & Moderate & - & Restricted \\
\hline $\begin{array}{c}\text { ECw }\left(\mathrm{dS} \mathrm{m} \mathrm{m}^{-1}\right) \\
\text {-water Electrical } \\
\text { Conductivity }\end{array}$ & $<0.7$ (No restriction) & - & $\begin{array}{c}0.7-3.0 \text { (Slight to } \\
\text { moderate restriction) }\end{array}$ & - & $\begin{array}{l}>3.0 \text { (Severe } \\
\text { restriction) }\end{array}$ \\
\hline $\begin{array}{l}\text { IM-Irrigation } \\
\text { Method }\end{array}$ & Drip & - & - & - & Surface or Sprinkler \\
\hline $\begin{array}{c}\mathrm{SAR}_{3} \wedge \mathrm{EC}_{\mathrm{W}}\left(\mathrm{dS} \mathrm{m}^{-1}\right) \\
3 \text {-water Sodium } \\
\text { Adsorption Ratio and } \\
\text { Electrical } \\
\text { Conductivity }\end{array}$ & $\begin{array}{l}\text { SAR 0-3 and } \\
\mathrm{EC}_{\mathrm{W}}>0.7 \text { (No } \\
\text { restriction) }\end{array}$ & - & $\begin{array}{c}\text { SAR } 0-3 \text { and } \\
0.2<\mathrm{EC}_{\mathrm{W}}<0.7 \\
\text { (Slight to moderate } \\
\text { restriction) }\end{array}$ & - & $\begin{array}{c}\text { SAR } 0-3 \text { and } \\
\text { EC }_{W}<0.2 \text { (Severe } \\
\text { restriction) }\end{array}$ \\
\hline
\end{tabular}
in the irrigation water, in meq $\mathrm{L}^{-1}$.

Table 3. Indicators, classification method, and rating scores considered in the RSA and RSO indices (adapted from [18]).

${ }^{1}$ After the United Nations Environmental Programme (UNEP) classification [27]. ${ }^{2}$ Good: Sand and Loamy Sand; Moderate: Sandy Loam, Sandy Clay Loam, Loam, Clay Loam, Silty Clay Loam, Silty Loam, and Silt; Restricted: Sandy Clay, Silty Clay, and Clay; a restricted drainage class was assigned whenever soil use capacity was severely to very severely limited due to excess water [18]. ${ }^{3}$ For different SAR values, different $\mathrm{EC}_{\mathrm{W}}$ intervals apply [28].

From the RSA values, five risk classes were assigned, namely: Very Low, RSA $<7$; Low, $7 \leq \mathrm{RSA} \leq 10$; Moderate, $11 \leq \mathrm{RSA} \leq 14 ;$ High, $15 \leq \mathrm{RSA} \leq 18$; Very High, RSA $>18$. In the case of RSO values, the classes considered were: Very Low, RSO $<8$; Low, $8 \leq \mathrm{RSO} \leq 12$; Moderate, $13 \leq \mathrm{RSO} \leq 17$; High, $18 \leq \mathrm{RSO} \leq 22$; Very High, RSO $>22$.

\subsection{Data Collection, Sampling, and Physical-Chemical Analyses}

The RSA and RSO indices were applied at two different spatial scales of assessment, respectively, the hydro-agricultural area level and crop field level. The assessment was 
performed during 2018. The collection of data and map building for some indicators varied from large databases and maps to in situ measurements, as presented in Table 4.

Soil sampling was carried out at the beginning (March-April) and at the end (OctoberNovember) of the crops' cycle and consisted of collecting a composed sample of every approximate 5 ha area, obtained from a mixture of sub-samples collected at randomly selected points following a zigzag trajectory, totaling 175 georeferenced points and 27 composed samples [29]. Soil texture was obtained by $\leq 2 \mathrm{~mm}$-sieving and a particle size analysis, following the ISO 11277:2020 method by sieving and sedimentation [30].

Table 4. Scales of evaluation, data sources, and estimation methods for the application of the RSA and RSO indices.

\begin{tabular}{|c|c|c|}
\hline \multirow{2}{*}{ Indicator } & \multicolumn{2}{|c|}{ Data Sources and Estimation Methods } \\
\hline & Hydro-Agricultural Area & Crop Fields \\
\hline $\mathrm{AI}$ & \multicolumn{2}{|c|}{$\begin{array}{l}\text { Ratio P/ETP [27]; P and ETP obtained from the ERA5 dataset of Monthly-mean averages values. ERA5 is the } \\
\text { fifth-generation reanalysis product provided by the European Centre for Medium-Range Weather Forecasts } \\
\text { (ECMWF; [31]) }\end{array}$} \\
\hline $\mathrm{Sl}$ & \multicolumn{2}{|c|}{ Portuguese soil and land use capacity chart [32] } \\
\hline SD & $\begin{array}{l}\text { Estimated from textural classes of the surface } \\
\text { horizons/layers of the predominant soil units in the } \\
\text { Portuguese soil and land use capacity chart [32] }\end{array}$ & $\begin{array}{l}\text { Estimated from textural classes determined from } \\
\text { particle size distribution of soil samples }\end{array}$ \\
\hline $\mathrm{ECw}$ & $\begin{array}{l}\text { Evaluation of the reservoir water quality for } \\
\text { irrigation according to the FAO guidelines [28] }\end{array}$ & $\begin{array}{l}\text { Evaluation of the hydrants' water quality for } \\
\text { irrigation according to the FAO guidelines [28] }\end{array}$ \\
\hline $\mathrm{IM}$ & $\begin{array}{l}\text { A probable irrigation method is assigned based on } \\
\text { the chart of Land Use and Occupation (COS2018) in } \\
\text { Continental Portugal, made available from the } \\
\text { Portuguese Directorate General for Territory } \\
\text { (DGT-Direç̧ão-Geral do Território) [33] }\end{array}$ & $\begin{array}{c}\text { Actual data of crop occupation made available from } \\
\text { the Alqueva Development and Infrastructures } \\
\text { Company (EDIA-Empresa de Desenvolvimento e } \\
\text { Infraestruturas de Alqueva) [34] }\end{array}$ \\
\hline $\mathrm{SAR} \wedge \mathrm{EC}_{\mathrm{W}}$ & $\begin{array}{l}\text { Evaluation of the reservoir water quality for } \\
\text { irrigation according to the FAO guidelines [28] }\end{array}$ & $\begin{array}{l}\text { Evaluation of the hydrants' water quality for } \\
\text { irrigation according to the FAO guidelines [28] }\end{array}$ \\
\hline
\end{tabular}

AI-Aridity Index; Sl—Slope; SD—Soil Drainage class; $\mathrm{EC}_{\mathrm{W}}$-Irrigation water Electrical Conductivity; IM-Irrigation Method; $\mathrm{SAR} \wedge \mathrm{EC}_{\mathrm{W}}$-Irrigation water Sodium Adsorption Ratio and Electrical Conductivity.

The study covered four water sampling campaigns, performed in April (Apr), July (Jul), October (Oct), and November (Nov). The sampling sites at the reservoirs included two in the Laje reservoir-Laje (L) and Laje Saída (LS), and at the Laje Estação Elevatória (LE) - and one in the Montinhos reservoir (M). For the local assessment, water samples were collected from eight irrigation hydrants, namely, H5, H6, H6, H21, H22, H23, H33 (water from Laje), and H16 (water conveyed from Montinhos). At each sampling location in the reservoirs, $2 \mathrm{~L}$ of surface water were collected, at a depth of $50 \mathrm{~cm}$, using a Van Dorn bottle, and then stored in polyethylene bottles. At the hydrants, $2 \mathrm{~L}$ water samples were collected in polyethylene bottles. The water samples were transported to the laboratory, in a cooler at $4{ }^{\circ} \mathrm{C}$, and stored, following the requisites for water conservation for each parameter [35]. The concentrations of $\mathrm{Ca}^{2+}, \mathrm{Mg}^{2+}$, and $\mathrm{Na}^{+}$were determined by the ionic chromatography methodology [35]. Water $\mathrm{EC}_{\mathrm{W}}$ in the reservoirs was measured in situ at the same dates at a $50 \mathrm{~cm}$ depth using a multiparametric probe, YSI 6820 MPS probe. In the case of the hydrants' water samples, $\mathrm{EC}_{\mathrm{W}}$ was determined in the laboratory by conductometry. Values of SAR were calculated after Equation (3).

For the AHA scale assessment, a spatial combination of maps of the different classes of indicators was made to obtain the final risk maps. The risk assessment of the crop fields was incorporated in these maps. For this purpose, the 125 ha area of the ten monitored plots was that of the polygon delimited by the sampling point distribution. The areas were obtained using the QGIS (version 3.12.3) built-in function. The comparison analysis between the results obtained for the area of study applying the general methodology at the regional scale and those obtained from the Fitofarmgest sampling points was conducted considering 
that the points were homogeneously distributed in the polygon with a known area. In this way, the area that maintained (or changed) the risk class in each case was obtained considering that it was directly proportional to the number of points that maintained (or changed) the classification, as given in Equation (4):

$$
A_{m / c}=\frac{A_{p} \times S P_{m / c}}{S P}
$$

where $A_{m / c}$ is the area that maintained $(m)$ or changed $(c)$ the classification; $A_{p}$ is the area of the polygon; $S P$ is the number of sampling points in the polygon; and $S P_{m / c}$ is the number of sampling points that maintained $(m)$ or changed $(c)$ the classification.

\section{Results and Discussion}

\subsection{Indicators}

The aridity index ranged between 0.28 and 0.29 ; therefore, the entire area of the AHA, including the monitored plots, presented a semi-arid climate (0.20-0.50) according to the classification of UNEP (1993; [27]). An extensive part of the area (76.7\%) presented slopes between $3 \%$ and $8 \%$, included in class II, according to the risk methodology calculation (Figure 2). Steeper terrain (class I) only occurred in $12.7 \%$ of the AHA, and flat terrain (class III) occurred on $10.6 \%$ of the total area.

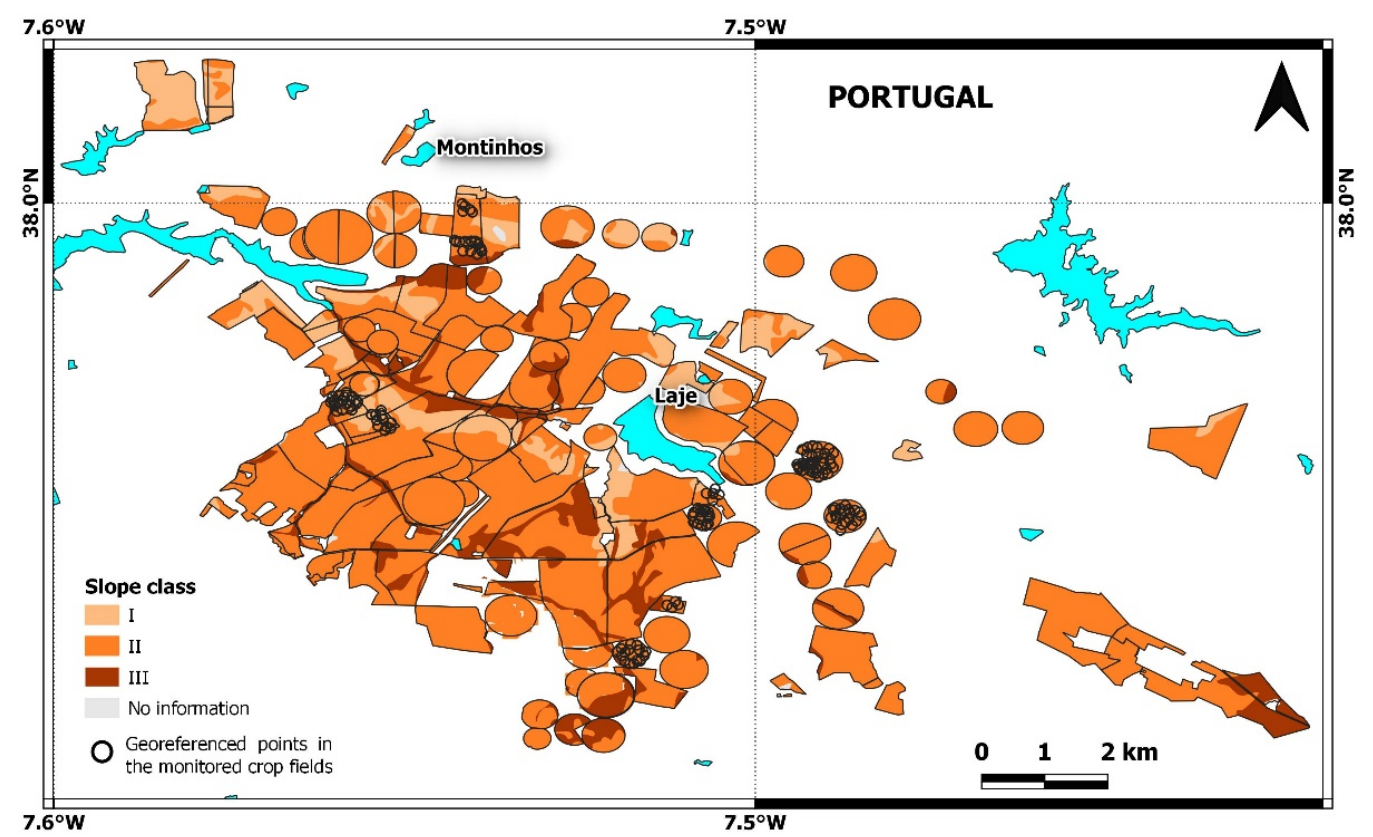

Figure 2. Slope classes in the AHA of Brinches-Enxoé. I: >9\%; II: 3-8\%; III: 0-2\%. The black open circles represent the monitored crop fields.

The drainage class evaluation at the farm plots, obtained from the texture determined by the soil particle size analysis, showed that about $69 \%$ of the monitored area had different classes of drainage when compared with the drainage class estimated for the AHA (Figure 3). Mainly, the variation occurred from poorly drained soils (grouped in Class III) in the AHA scale assessment, to moderately drained (grouped in Class II) in the crop field scale assessment, therefore indicating a prevalence of medium textures determined in the soil samples. Such differences point to a spatial variability in the soil texture comprised by each soil unit area that is not translated by the Portuguese Soil Chart (scale 1:25,000), which is the source for the drainage estimation at a regional scale. 

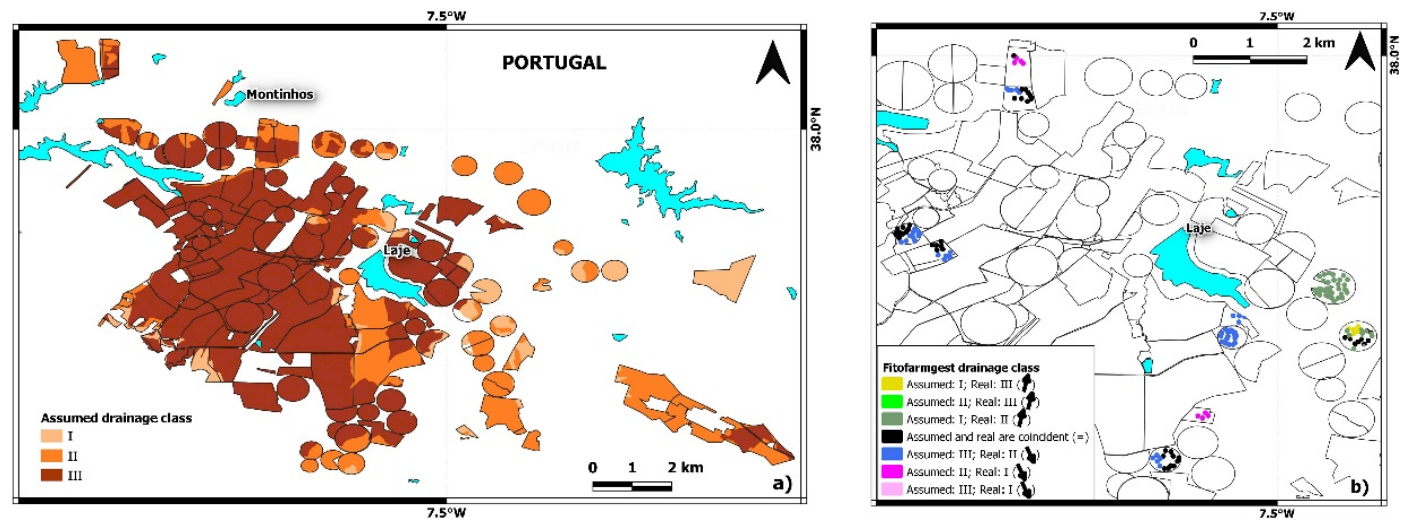

Figure 3. Soil drainage classes in the AHA of Brinches-Enxoé (a) and in the monitored crop fields (b), displaying the similarities and differences of the two scales of evaluation. I: Good; II: Moderate; III: Restricted.

Regarding the land use and irrigation method, there was a change in the classification in $24 \%$ of the monitored area when using actual data (Figure 4). At the AHA scale, when assigning a probable irrigation method from the land occupation in COS2018, the class of temporary crops was considered as potentially irrigated with sprinkler systems. This assumption implies that fields actually occupied by permanent crops, irrigated by drip irrigation systems were wrongly assumed to be under sprinkler irrigation.
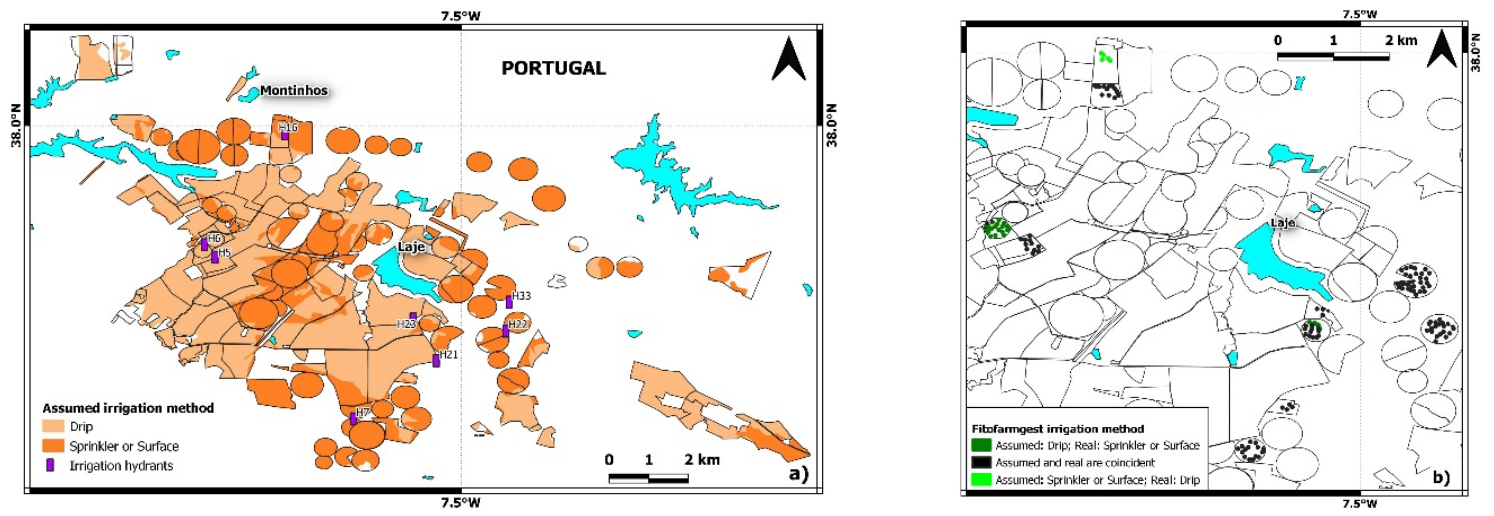

Figure 4. Irrigation methods in the AHA of Brinches-Enxoé (a) and in the monitored crop fields (b), displaying the similarities and differences of the two scales of evaluation.

The temporal variation observed for $\mathrm{EC}_{\mathrm{W}}$ and SAR in the reservoirs (Laje and Montinhos) is presented in Figure 5. In the case of $\mathrm{EC}_{\mathrm{W}}$, the highest average values were measured in April in both reservoirs. As for SAR, the highest values were registered at Laje Estação Elevatória (LE) in April and July. These higher values in Spring and early Summer could be due to the 2017 and early 2018 drought, with low precipitation rates that led to low water storage and, possibly, reduced salt dissolution.

In the case of the irrigation hydrants, $\mathrm{H} 23$ (water supplier to farm plots $\mathrm{S} 1$ - sunflower and G1-grapevine) presented the higher values of $\mathrm{EC}_{\mathrm{W}}$ throughout the year, while $\mathrm{H} 33$, which supplied irrigation water to Alfalfa (A), showed the highest SAR value, in October (Figure 6). Regardless of these slight variations, and according to the methodology of salinization and sodification risk prediction, the irrigation water quality indicators fall in the same classes for both the regional and local scales of assessment, namely, for RSA estimation, the $\mathrm{EC}_{W}$ values showed no degree of restriction of use and for RSO estimation, the combined $\mathrm{EC}_{\mathrm{W}}$ and $\mathrm{SAR}$ values indicated a slight-to-moderate degree of restriction of use in all water samples. 

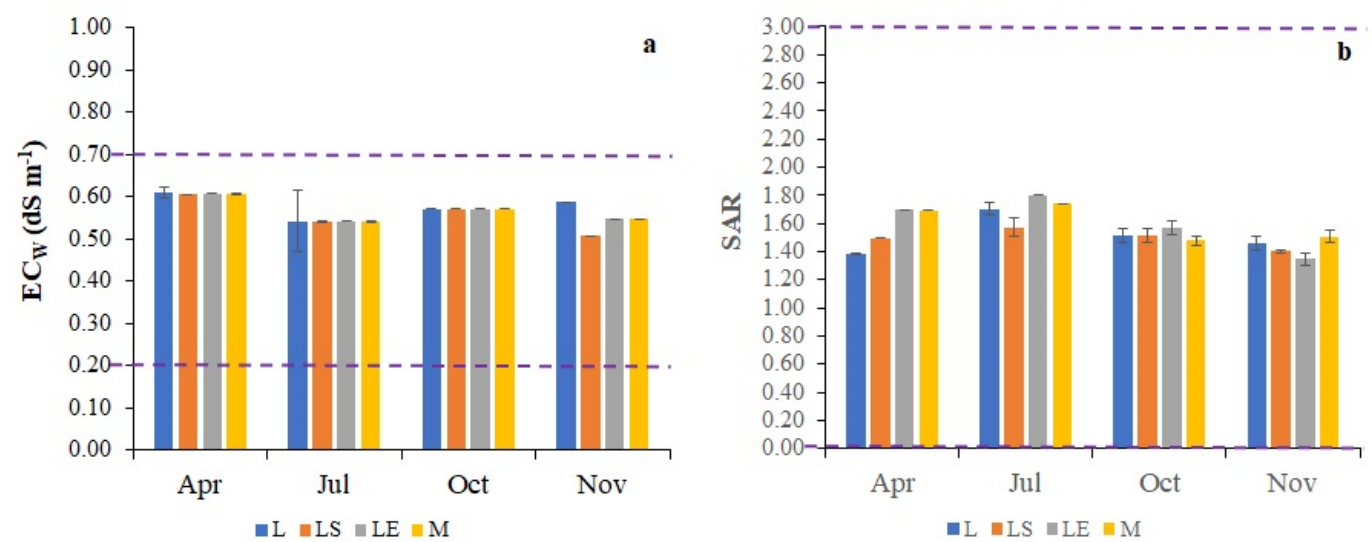

Figure 5. Spatial and temporal variation of $\mathrm{EC}_{W}(\mathbf{a})$ and $\mathrm{SAR}(\mathbf{b})$, during 2018, at three sites in the Laje reservoir and one site at the Montinhos reservoir. Bars represent the mean, and whiskers represent the standard deviation for three repetitions. Dashed purple lines correspond to the limit values from FAO water quality standards as presented in Table 3. L-Laje; LS—Laje Saída; LE—Laje Estação Elevatória; M-Montinhos. Apr-April; Jul—July; Oct_October; Nov—November.
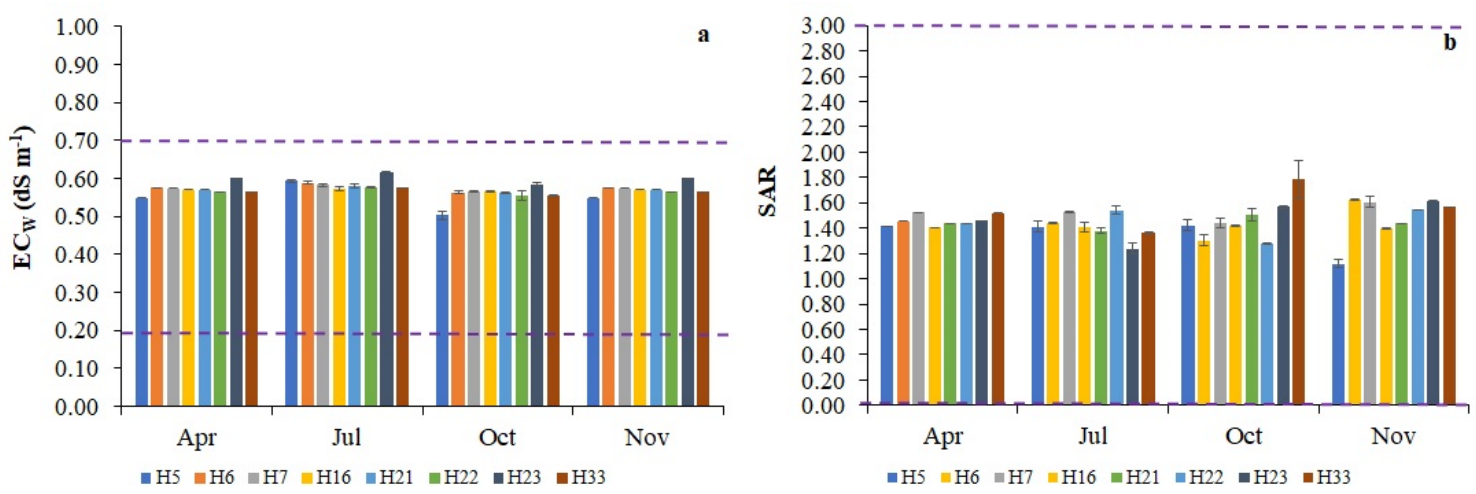

Figure 6. Spatial and temporal variation of $\mathrm{EC}_{W}(\mathbf{a})$ and SAR (b), during 2018, at eight irrigation hydrants. Bars represent the mean, and whiskers represent the standard deviation for three repetitions Dashed purple lines correspond to the limit values from FAO water quality standards as presented in Table 3. Apr-April; Jul—July; Oct—October; Nov—November.

\subsection{Maps of Salinization and Sodification Risk}

The risk map of soil salinization in the AHA of Brinches-Enxoé shows that there was a predominance of Moderate risk areas (55\%), followed by Low (43\%), and Very Low risk $(2 \%)$. There were no areas within the higher risk classes (Figure 7). However, when evaluating at the crop field scale, the Low-risk areas prevail $(71 \%)$, and the remaining areas of the plots are of Moderate risk of salinization (29\%). The moderate risk of salinization zones was mainly associated with fine textured soils and flat to low slope terrain (slopes $\leq 2 \%$ ). In general, $38.2 \%$ of the total crop fields' area changed their risk class of salinization, with the differences resulting mainly from the reduction in scores for soil drainage, which, as explained in Section 3.1, were lower due to an actual prevalence of moderately drained terrain in the monitored fields. 

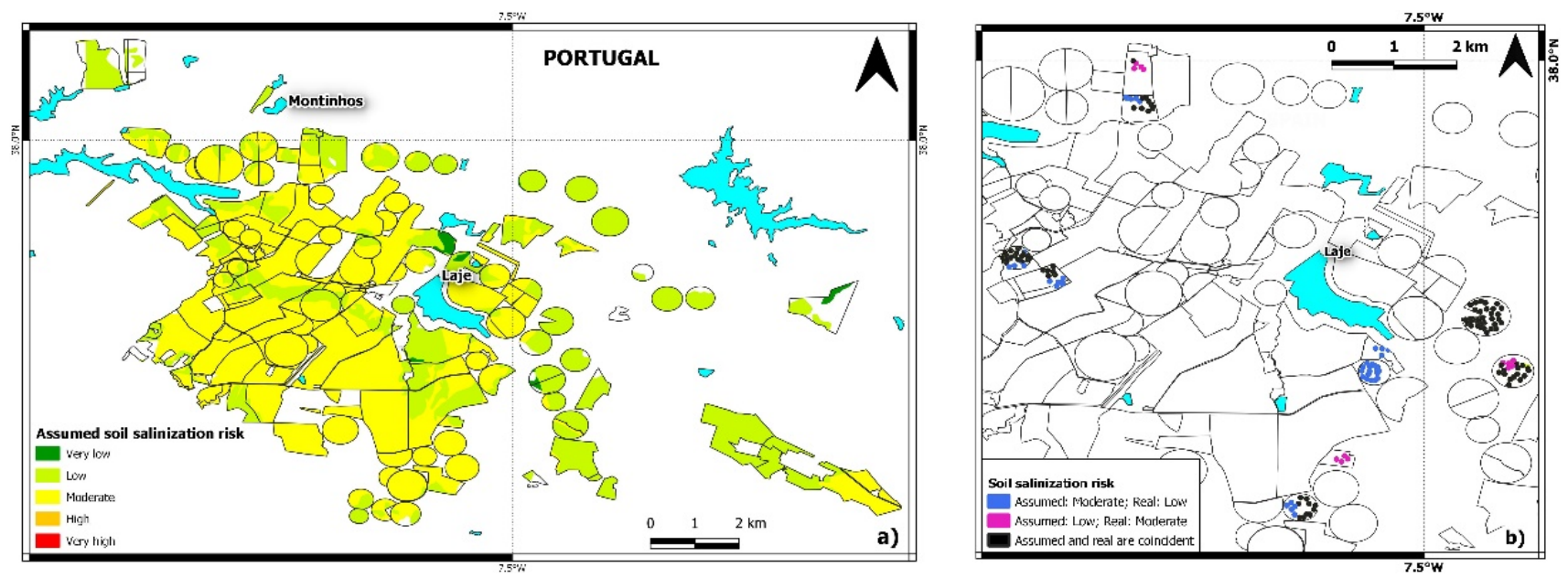

Figure 7. Salinization risk in the AHA of Brinches-Enxoé (a) and in the monitored crop fields (b) based on the Salinization Risk index (RSA). Similarities and differences of the two scales of evaluation are displayed. Very Low risk: RSA < 7; Low risk: $7 \leq \mathrm{RSA} \leq 10$; Moderate risk: $11 \leq \mathrm{RSA} \leq 14$; High risk: $15 \leq \mathrm{RSA} \leq 18$; Very High risk: RSA $>18$.

The risk map of soil sodification can be observed in Figure 8. Considering the first tier evaluation, in the AHA of Brinches-Enxoé, the predominant risk class is Moderate $(68.0 \%)$, followed by High (25.3\%), and Low risk (6.6\%) classes. In the second tier, Moderate risk areas represent $84.0 \%$, and the remaining area is of High risk of sodification. Areas with high RSO resulted mostly from under sprinkler irrigated crops in the low slope terrain, with fine textured soils. The differences for the two scales of assessment occurred in $21.0 \%$ of the fields area and are mostly deviations in a "positive" direction, i.e., from higher to lower risk. Again, the explanation for the differences relies on the reduction in scores for drainage but also, in the case of this index, on the assigned probable irrigation method based on the land occupation classes in COS2018, as referred to in Section 3.1.
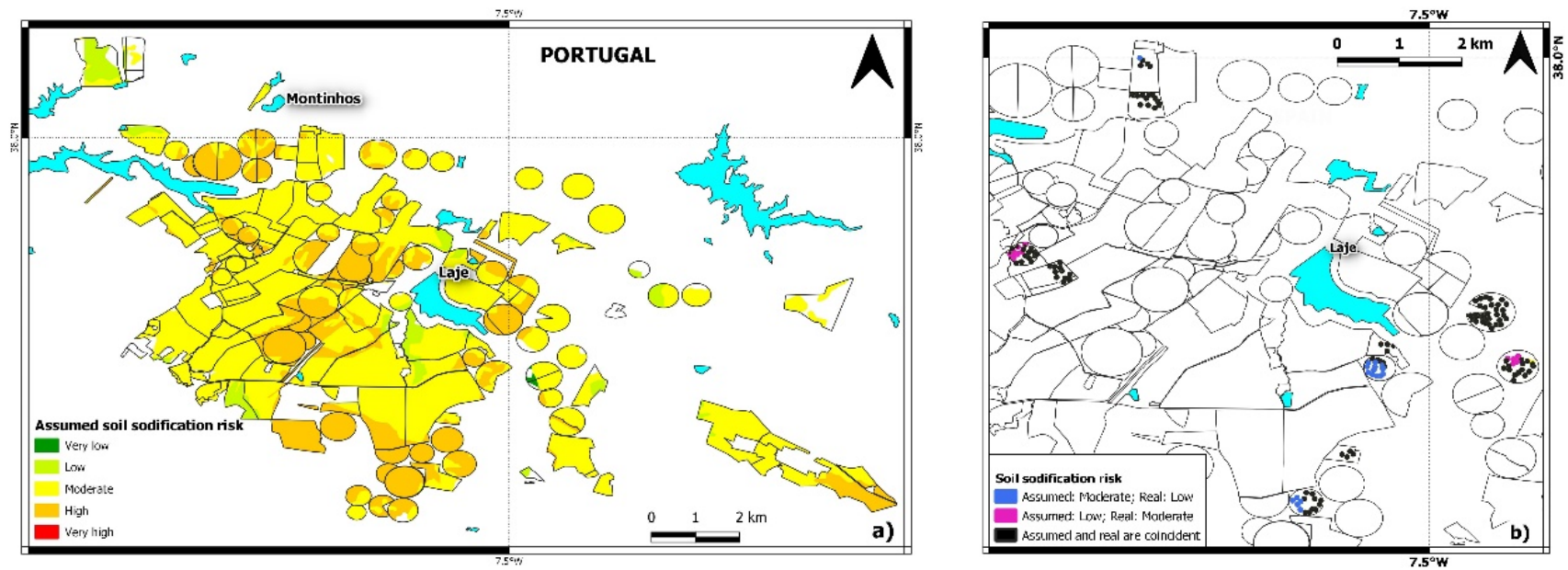

Figure 8. Sodification risk in the AHA of Brinches-Enxoé (a) and in the Fitofarmgest crop fields (b) based on the Sodification Risk index (RSO). Similarities and differences of the two scales of evaluation are displayed. Very Low risk: RSO < 8; Low risk: $8 \leq \mathrm{RSO} \leq 12$; Moderate risk: $13 \leq \mathrm{RSO} \leq 17$; High risk: $18 \leq \mathrm{RSO} \leq 22$; Very High risk: RSO $>18$.

Overall, given that most of the area in the monitored crop fields presents the same risk classes (62\% in RSA and 78\% in RSO), it is feasible to apply both the RSA and RSO for regional/landscape and local/farm scale assessment. For this purpose, a tolerable increase in error can be accepted when the spatial resolution becomes lower and assuming that the identification of soil salinization and sodification risk "Hot Spots" is the primary aim of the assessment [36]. 


\subsection{Hints for Risk Management of Salinization and Sodification in Irrigated Agroecosystems}

According to the International Organization for Standardization (ISO) guideline for risk management (ISO 31000:2018), the risk management process involves the systematic application of policies, procedures, and practices to the activities of communicating and consulting, establishing the context and assessing, treating, monitoring, reviewing, recording, and reporting risk [37]. Risk assessment is the overall process of risk identification, risk analysis, and risk evaluation, and it is followed by the risk treatment stage, where options for addressing risk, through its mitigation, should be selected and implemented. This common approach to managing any type of risk may be applied to the risk management of salinization and sodification in irrigated agroecosystems (Figure 9). In this case, risk assessment methods may allow for the identification of sensitive areas where preventive measures or adaptative agronomic options are needed [38]. Different spatial scales are associated with different objectives and measures whose sequence and integration are necessary as a function of the risk assessed. Therefore, for the prevention and mitigation of soil salinization and sodification related to anthropogenic activities, such as irrigation, a multi-scale and holistic perspective should be considered.

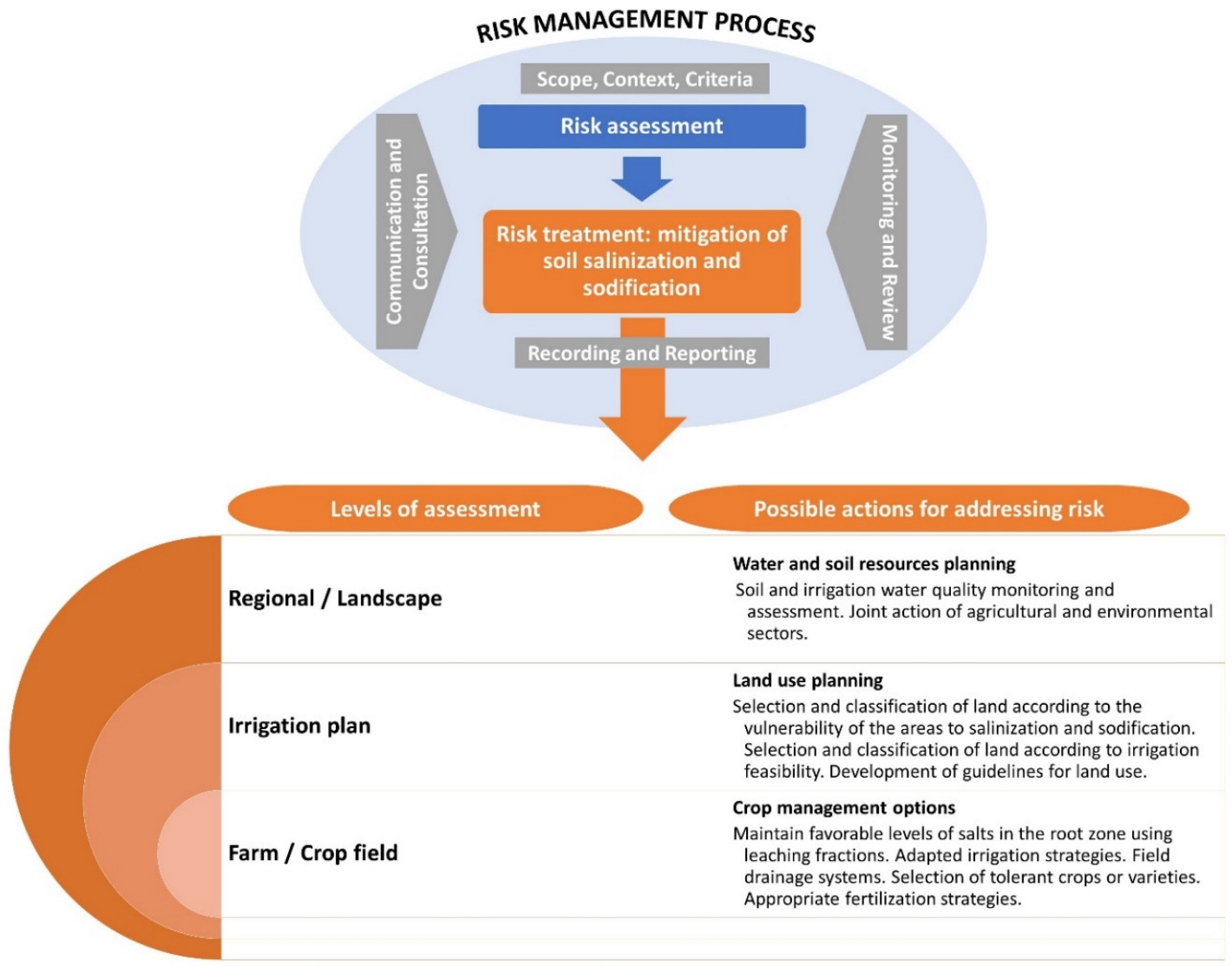

Figure 9. Outline of a salinization and sodification risk management process based on ISO 31000:2018 [37] with risk treatment stage adapted to different spatial levels of assessment.

The following scales are proposed:

- Regional scale: management and planning of water and soil resources-long term irrigation water and soil quality assessment regarding its uses (involves the strengthening of actions and links between institutions in the agricultural and environmental sectors responsible for the implementation of resource-planning policies).

- Irrigation plan/perimeter scale: land use planning-selection and classification of land according to the vulnerability of the areas to salinization and sodification processes; 
selection and classification of land according to irrigation feasibility; development of guidelines for land use.

- Farm/crop scale: crop management options-maintain favorable levels of salts in the root zone through the use of leaching fractions; adapted irrigation and field drainage strategies; selection of tolerant crops or varieties; other agronomic practices for prevention and mitigation.

Methods of salinity prevention and mitigation also vary as a function of the level of risk assessed. For instance, in high-risk areas, it may be necessary to monitor the groundwater levels, the amount of salt in the soils, and / or the irrigation water quality, while at moderate risk areas, the adoption of cropping practices that minimize water logging can be recommended [39]. From a farm/crop field management viewpoint, differentiation can also be established for each risk class, from the appliance of salt amendments and leaching fractions in higher risk areas, to the adoption of improved irrigation practices, such as methods with higher irrigation efficiency and uniformity, or increased irrigation frequency, in the case of moderate to low risk zones [21].

Under a regional/landscape perspective, soil salinization mitigation in irrigation areas should involve long-term irrigation water quality monitoring and assessment programs, including sampling campaigns covering different periods in the wet and dry seasons, particularly under drought conditions [10,21]. For smaller areas, as is the case of farms and agricultural fields, higher detail can be applied for the control of soil and water salinity and sodicity. The recommendation of preventive irrigation practices, such as maintenance leaching applications and properly designed drainage systems, should be considered $[20,40,41]$. In salt-sensitive areas, irrigation should aim to achieve a sustainable salt balance in the soil profile. For this, frequent irrigation events and schedules providing crops' leaching requirements and adapted to the crop salt tolerance and selected irrigation method are usually encouraged [4,42]. The judicious use of multi-quality waters' blending is also indicated by Rhoades et al. [20], Qadir and Oster [43], and Phogat et al. [44]. Since crop fertilization can be a source of salts in the soil, the appropriate timing and fractioning of fertilizers' application should be considered [45]. When salinity is associated with shallow and saline groundwater, provisions for surface/sub-surface drainage systems further help in aeration, lateral water flows for salt removal, and trafficability [20,42].

\section{Conclusions}

This study used two risk indices to predict salinization and sodification in a hydroagricultural area in Southern Portugal and ten farm plots within that area, aiming at the comparison and adaptability of the risk indices to different spatial scales of evaluation. Low and moderate salinization risk areas prevailed in the study area. Regarding sodification, moderate risk was the predominant class. The results revealed the feasibility of using the RSA and RSO indices both on large and smaller scales, as most of the area in the monitored crop fields presented the same risk classes (62\% in RSA and 78\% in RSO). Deviations were due to the reduction in scores for drainage and, in the case of RSO, the assigned irrigation method based on the land occupation class. Nevertheless, these deviations were mostly in a "positive" direction, from higher to lower risk classes of salinization and sodification risk.

The study outlined a risk management framework applied to soil salinization and sodification in irrigated areas adapting the ISO guidelines. The framework considered that different spatial scales are associated with different objectives and measures whose sequence and integration are necessary. Therefore, a multi-scale perspective for mitigation actions in salt-sensitive areas was delineated, ranging from territorial planning to the adoption of on-farm practices that can contribute to the sustainability of irrigated agriculture.

Author Contributions: Conceptualization, A.T., M.J.C. and P.P.; methodology, A.T., M.J.C. and P.P.; validation, A.T., J.D., I.G., M.M.P., M.F., L.B., M.P. and P.P.; investigation, A.T., M.J.C., J.C., J.D., A.C., I.M., C.M., I.G., M.M.P., M.F., L.B., M.P. and P.P.; writing—original draft preparation, A.T.; 
writing—review and editing, A.T., M.J.C., J.C., I.G., M.M.P., M.F., L.B., M.P. and P.P.; visualization, M.J.C.; supervision, P.P.; project administration, P.P.; funding acquisition, A.T., M.J.C., J.C., M.P. and P.P. All authors have read and agreed to the published version of the manuscript.

Funding: This research is co-funded by the European Union through the European Regional Development Fund, included in the COMPETE 2020 (Operational Program Competitiveness and Internationalization) through the ICT project (UIDB/04683/2020), with the reference POCI-01-0145-FEDER-007690, through Geobiotec (UIDB/04035/2020) and Centro de Química (UIBD/00616/2020)funded by FCTFundação para a Ciência e a Tecnologia, Portugal, and through the FitoFarmGest Operational Group (PDR2020-101-030926).

Institutional Review Board Statement: Not applicable.

Informed Consent Statement: Not applicable.

Acknowledgments: The authors thank the General Directorate of Agriculture and Rural Development of Portugal (DGADR—Direção Geral de Agricultura e Desenvolvimento Rural) and the Alqueva Development and Infrastructures Company (EDIA-Empresa de Desenvolvimento e Infraestruturas do Alqueva) for providing, respectively, the Portuguese soil and land use capacity maps, and the Alqueva crop occupation map in digital form.

Conflicts of Interest: The authors declare no conflict of interest. The funders had no role in the design of the study; in the collection, analyses, or interpretation of data; in the writing of the manuscript; or in the decision to publish the results.

\section{References}

1. Nuñez, M.; Tóth, T. Ecosystem Services and Salinisation. In Final Report of the EIP-AGRI Focus Group: Soil Salinisation; European Comission: Brussels, Belgium, 2020; p. 10.

2. Adhikari, K.; Hartemink, A.E. Linking Soils to Ecosystem Services-A Global Review. Geoderma 2016, 262, 101-111. [CrossRef]

3. Richards, L.A. Diagnosis and Improvement of Saline and Alkali Soils; Agriculture Handbook; USDA: Washington, DC, USA, 1954; Volume 60 .

4. Minhas, P.S.; Ramos, T.B.; Ben-Gal, A.; Pereira, L.S. Coping with Salinity in Irrigated Agriculture: Crop Evapotranspiration and Water Management Issues. Agric. Water Manag. 2020, 227, 105832. [CrossRef]

5. Weil, R.R.; Brady, N.C. The Nature and Properties of Soils, 15th ed.; Pearson: Columbus, OH, USA, 2016; ISBN 978-0-13-325448-8.

6. Rengasamy, P. Soil Processes Affecting Crop Production in Salt-Affected Soils. Funct. Plant. Biol. 2010, 37, 613. [CrossRef]

7. Qadir, M.; Quillérou, E.; Nangia, V.; Murtaza, G.; Singh, M.; Thomas, R.J.; Drechsel, P.; Noble, A.D. Economics of Salt-Induced Land Degradation and Restoration. Nat. Resour. Forum. 2014, 38, 282-295. [CrossRef]

8. Mateo-Sagasta, J.; Burke, J. Agriculture and Water Quality Interactions: A Global Overview; SOLAW Background Thematic ReportTR08; Food and Agriculture Organization of the United Nations: Rome, Italy, 2010.

9. Stolte, J.; Tesfai, M.; Øygarden, L.; Kværnø, S.; Keizer, J.; Verheijen, F.; Panagos, P.; Ballabio, C.; Hessel, R. Soil Threats in Europe; JCR Technical Report; European Comission: Brussels, Belgium, 2016.

10. Tomaz, A.; Palma, P.; Fialho, S.; Lima, A.; Alvarenga, P.; Potes, M.; Salgado, R. Spatial and Temporal Dynamics of Irrigation Water Quality under Drought Conditions in a Large Reservoir in Southern Portugal. Environ. Monit. Assess. 2020, 192, 93. [CrossRef] [PubMed]

11. Tomaz, A.; Palma, P.; Alvarenga, P.; Gonçalves, M.C. Chapter 13-Soil salinity risk in a climate change scenario and its effect on crop yield. In Climate Change and Soil Interactions; Prasad, M.N.V., Pietrzykowski, M., Eds.; Elsevier: Amsterdam, The Netherlands, 2020; pp. 351-396. ISBN 978-0-12-818032-7.

12. Yeo, A. Predicting the Interaction between the Effects of Salinity and Climate Change on Crop Plants. Sci. Hortic. 1998, 78, 159-174. [CrossRef]

13. Zalidis, G.; Stamatiadis, S.; Takavakoglou, V.; Eskridge, K.; Misopolinos, N. Impacts of Agricultural Practices on Soil and Water Quality in the Mediterranean Region and Proposed Assessment Methodology. Agric. Ecosyst. Environ. 2002, 88, 137-146. [CrossRef]

14. Singh, A. Soil Salinization and Waterlogging: A Threat to Environment and Agricultural Sustainability. Ecol. Indic. 2015, 57, 128-130. [CrossRef]

15. Muyibul, Z.; Jianxin, X.; Muhtar, P.; Qingdong, S.; Run, Z. Spatiotemporal Changes of Land Use/Cover from 1995 to 2015 in an Oasis in the Middle Reaches of the Keriya River, Southern Tarim Basin, Northwest China. Catena 2018, 171, 416-425. [CrossRef]

16. Bloem, E.; van der Zee, S.E.A.T.M.; Tóth, T.; Hagyo, A. Risk Assessment Methods of Salinity; Report EUR 24097 EN; Publications Office of the European Union: Luxembourg, 2008; ISBN 978-92-79-14291-8.

17. Shahid, S. Developments in Soil Salinity Assessment, Modeling, Mapping, and Monitoring from Regional to Submicroscopic Scales; Shahid, S., Abdelfattah, M., Taha, F., Eds.; Springer: Dordrecht, The Netherlands, 2013; pp. 3-43, ISBN 978-94-007-5683-0. 
18. Tomaz, A.; Palma, P.; Fialho, S.; Lima, A.; Alvarenga, P.; Potes, M.; Costa, M.; Salgado, R. Risk Assessment of Irrigation-Related Soil Salinization and Sodification in Mediterranean Areas. Water 2020, 12, 3569. [CrossRef]

19. Chartzoulakis, K.S. The Use of Saline Water for Irrigation of Olives: Effects on Growth, Phisiology, Yield and Oil Quality. Acta Hortic. 2011, 888, 97-108. [CrossRef]

20. Rhoades, J.D.; Kandiah, A.; Mashali, A.M. The Use of Saline Waters for Crop. Production; FAO Irrigation and Drainage Paper; Food and Agriculture Organization of the United Nations: Rome, Italy, 1992; ISBN 978-92-5-103237-4.

21. Hillel, D. Salinity Management for Sustainable Irrigation: Integrating Science, Environment, and Economics; The World Bank: Washington, DC, USA, 2000; ISBN 978-0-8213-4773-7.

22. Ren, D.; Wei, B.; Xu, X.; Engel, B.; Li, G.; Huang, Q.; Xiong, Y.; Huang, G. Analyzing Spatiotemporal Characteristics of Soil Salinity in Arid Irrigated Agro-Ecosystems Using Integrated Approaches. Geoderma 2019, 356, 113935. [CrossRef]

23. IPMA. Climate Normals-1981-2010-Beja. Available online: https://www.ipma.pt/en/oclima/normais.clima/1981-2010/002/ (accessed on 6 July 2019).

24. IUSS Working Group WRB. World Reference Base for Soil Resources 2014, Update 2015; FAO: Rome, Italy, 2014.

25. Madeira, M.; Monteiro, F. A Base de Referência Para Os Solos Do Mundo e a Classificação Dos Solos de Portugal. Rev. De Cienc. Agrárias 2004, 27, 13-23.

26. Lopes, R.; Madeira, M.; Arsénio, P. Mapping of Land Units and Land Capability Classification in Portugal. The Case of Lourinhã Municipality. Finisterra 2017, 52, 103-127. [CrossRef]

27. UNEP. World Atlas of Desertification; The United Nations Environmental Programme: London, UK, 1993.

28. Ayers, R.S.; Westcot, D.W. Water Quality for Agriculture; FAO Irrigation and Drainage Paper; Food and Agriculture Organization of the United Nations: Rome, Italy, 1985; ISBN 978-92-5-102263-4.

29. Varennes, A.D. Produtividade Dos Solos e Ambiente; Escolar Editora: Lisboa, Portugal, 2003.

30. International Organization for Standardization. Soil Quality—Determination of Particle Size Distribution in Mineral. Soil MaterialMethod by Sieving and Sedimentation (ISO Standard No. 11277:2020); International Organization for Standardization: London, UK, 2020; p. 16.

31. Hersbach, H.; Dee, D. ERA5 Reanalysis Is in Production. In ECMWF Newsletter; European Centre for Medium-Range Weather Forecasts: Reading, UK, 2016; 147p.

32. SROA/CNROA/IEADR Cartas de Solos e Capacidade de Uso (1:25000); Direção Geral de Agricultura e Desenvolvimento Rural: Lisbon, Portugal, 1960.

33. DGT Carta de Uso e Ocupação Do Solo (COS2018); Direção Geral do Território: Lisbon, Portugal, 2018.

34. EDIA Crop Occupation 2018; Empresa de Desenvolvimento e Infraestruturas de Alqueva: Beja, Portugal, 2018.

35. APHA. Standard Methods for the Examination of Water and Wastewater, 20th ed.; American Public Health Association, American Water Works Association and Water Environmental Federation: Washington, DC, USA, 1998.

36. Eckelmann, W.; Baritz, R.; Bialousz, S.; Bielek, P.; Carre, F.; Houskova, B.; Jones, R.J.A.; Kibblewhite, M.; Kozak, J.; le Bas, C.; et al. Common Criteria for Risk Area Identification According to Soil Threats; Office for Official Publications of the European Communities: Luxembourg, 2006.

37. International Organization for Standardization. Risk Management_Guidelines (ISO Standard No. 31000:2018); International Organization for Standardization: London, UK, 2018; p. 16.

38. Thompson, R.; Amezketa, E.; Nuñez, M.; Falsone, G.; Toth, T.; Paz, A.; Gonçalves, M.; Castanheira, N.; Gould, I.; Tamvakidis, S. EIP-AGRI Focus Group Soil Salinisation. Measuring, Mapping and Monitoring of Soil Salinity; The European Innovation Partnership: Brussels, Belgium, 2020.

39. Department of Environment and Resource Management. Salinity Management Handbook, 2nd ed.; Department of Environment and Resource Management: Queensland, Australia, 2011; ISBN 0-7242-7412-X.

40. Corwin, D.L.; Rhoades, J.D.; Šimůnek, J. Leaching Requirement for Soil Salinity Control: Steady-State versus Transient Models. Agric. Water Manag. 2007, 90, 165-180. [CrossRef]

41. Wallender, W.W.; Tanji, K.K. Agricultural Salinity Assessment and Management, 2nd ed.; American Society of Civil Engineers: Reston, VA, USA, 2011; ISBN 978-0-7844-1169-8.

42. Hanson, B.R.; Grattan, S.R.; Fulton, A. Agricultural Salinity and Drainage; Water Management Series publication; University of California Irrigation Program: Davis, CA, USA, 2006.

43. Qadir, M.; Oster, J.D. Crop and Irrigation Management Strategies for Saline-Sodic Soils and Waters Aimed at Environmentally Sustainable Agriculture. Sci. Total Environ. 2004, 323, 1-19. [CrossRef]

44. Phogat, V.; Mallants, D.; Cox, J.W.; Šimůnek, J.; Oliver, D.P.; Awad, J. Management of Soil Salinity Associated with Irrigation of Protected Crops. Agric. Water Manag. 2020, 227, 105845. [CrossRef]

45. Machado, R.; Serralheiro, R. Soil Salinity: Effect on Vegetable Crop Growth. Management Practices to Prevent and Mitigate Soil Salinization. Horticulturae 2017, 3, 30. [CrossRef] 